\title{
A threat-centered theory of policy entrepreneurship
}

\author{
Gwen Arnold ${ }^{1}$ (D)
}

Accepted: 18 November 2021 / Published online: 11 December 2021

(c) The Author(s) 2021

\begin{abstract}
We know relatively little about the conditions that encourage people to jump into the political fray as policy entrepreneurs, advocates who devote substantial time, energy, and resources to campaigning for a policy goal. This paper aims to fill that gap by investigating the catalysts of policy entrepreneurship in municipalities across the State of New York, where between 2008 and 2012, hundreds of local jurisdictions passed measures opposing or supporting high-volume hydraulic fracturing (fracking). These local policy actions were often enthusiastically encouraged and, in some cases, vociferously opposed, by enterprising advocates. I propose a threat-centered theory of policy entrepreneurship, emphasizing the role of loss aversion in pushing actors toward advocacy. The empirical analysis shows that oppositional advocacy within a polity draws would-be policy entrepreneurs into battle.
\end{abstract}

Keywords Policy entrepreneurship · Policy entrepreneur $\cdot$ Fracking $\cdot$ Devil shift $\cdot$ Loss aversion

\section{Introduction}

Policy science is centrally concerned with how, when, and why policy change occurs. One or a small number of key actors be helping achieve change by acting as "policy entrepreneurs... willing to invest their resources - time, energy, reputation, money - to promote a [policy] position in return for anticipated future gain in the form of material, purposive, or solitary benefits" (Kingdon, 1984, 3). But what factors determine where and when policy entrepreneurs emerge to champion change?

The limited existing scholarship on policy entrepreneur emergence draws on transaction cost and collective action theorizing to argue that resources, both to be gained by and in support of advocacy, spur people to spearhead efforts for policy change, while obstacles (e.g., lack of support from key constituencies) hinder their engagement. Yet this account is incomplete: People considering engaging in politics do not necessarily or only make rational, rent-seeking calculations; they also are driven by deeply held beliefs and the desire to see those beliefs effectuated in policy.

Gwen Arnold

gbarnold@ucdavis.edu

1 Department of Environmental Science and Policy, University of California Davis, 1 Shields Ave., Davis, CA 95616, USA 
I argue that when an individual perceives a substantial threat to a strongly hoped-for policy aim-specifically, when an opponent actively advocates for a conflicting goalthe individual becomes more likely to fight to preserve and advance their own policy vision. I test this proposition in the context of local high-volume hydraulic fracturing (fracking) policymaking in the State of New York, where between 2008 and 2012, hundreds of localities passed policies opposing or supporting fracking, often spurred on by anti- and pro-fracking advocates.

\section{Who are policy entrepreneurs?}

Policy entrepreneurs (PEs) try to encourage substantive policy change (King and Roberts, 1992; Kingdon, 1984; Mintrom \& Norman, 2009; Vallett, 2020) and alter the policy status quo by creatively "recombine[ing] intellectual, political, and organizational resources into new products and courses of action for government" (Oliver and Paul-Shaheen, 1997, 744). These actors, who may work within or outside government, are notable for the intensity and persistence of their efforts to secure desired policy outcomes and willingness to risk substantial investment of time, energy, and capital to do so (Anderson et al., 2020; Huitema and Meijerink, 2010; Font \& Subirats, 2010; Mintrom, 1997, 2019; Mack et al., 2008; Roberts \& King, 1991). They may act opportunistically and briefly or invest in advocacy over an extended period (Boasson \& Wettestad, 2014; Kingdon, 1984).

Policy entrepreneurs attempt to draw attention and resources to their cause (Mintrom, 1997; Mintrom et al., 2014; Ramamurti, 1986), seeking to "soften up the system," lobby decision-makers, secure allies, frame problems in ways favorable to and demonstrate efficacy of their preferred policy solutions, empower allies, and disseminate information (Anderson et al., 2020; Cairney, 2018; Weissert, 1991). Dogged in their pursuit of strategic advantage and influence, they tailor their advocacy to the realities of varied political contexts, seek and shift venues, and intervene at all stages of the policy process (Cairney, 2018; Font \& Subirats, 2010; Ferman, 1987 and Levin Mintrom, 1997). They build networks to gain allies, resources, and influence over political elites (Arnold et al., 2017; Huitema and Meijerink, 2010; Roberts \& King, 1991). Policy entrepreneurs figure prominently in many leading theories of the policy process, facilitating the coupling of problem, politics, and policy solutions (Multiple Streams Framework; see Cairney, 2018), helping shape and advance policy images in order to create and maintain policy monopolies (Punctuated Equilibrium Theory, see Brasil \& Capella, 2017), and propelling inter-jurisdictional policy diffusion (Stone, 2019; Vallett, 2020).

Although many studies of policy entrepreneurship focus on key individuals (e.g., Vallett, 2020), scholars increasingly recognize that those individuals may be part of a vanguard of committed advocates who work collaboratively (Mintrom, 2019; Stone, 2019). Collaborative policy entrepreneurship may be pursued by networks of actors in different positions/roles or by individuals representing an organization and advancing its policy agenda (e.g., Carter \& Childs, 2018; Boasson \& Wettestad, 2014; Anderton and Setzer, 2018). The present analysis follows the traditional approach of focusing on pivotal individuals because it is concerned with an individual's choice to pursue entrepreneurship—whether independently or collaboratively. 


\section{Conventional explanations for why policy entrepreneurs emerge}

The dominant explanation for policy entrepreneurship comes from a series of works by Schneider and Teske (), Schneider et al. (1995) and Teske and Schneider (1994), who identified and characterized conditions under which policy entrepreneurs emerge in US cities [see also Kim (1996), nearly fully replicating these results in South Korean municipalities]. More recently, Kalafatis and Lemos (2017), leaning in part on Schneider and Teske's theoretical framework, predicted emergence of climate policy entrepreneurs in U.S. Rust Belt cities. $^{1}$

The Schneider and Teske framework begins with Olson's (1965) argument that large groups of rational individuals rarely act jointly to achieve a shared goal, like policy change, preferring instead to free-ride on others' efforts. This dilemma can sometimes be overcome if a privileged actor takes on a disproportionate share of the work. For that actor to engage, she must perceive that resources to be gained from and available to support goal achievement are larger than the personal costs associated with obstacles she is likely to confront (ibid.).

In this context, obstacles are factors hindering a policy entrepreneur's efforts to organize or contribute to collective action favoring her cause. For example, city managers appear less likely to act entrepreneurially when the local public workforce is more unionized, as unions resist changes to status quo service provision (Teske \& Schneider, 1994); when a city relies on at-large rather than district elections, as the free-rider incentive and transaction costs make organizing in larger constituencies more difficult (Schneider \& Teske, 1993a; see also Kalafatis \& Lemos, 2017); and when local taxpayer groups are powerful, as they seek government spending reductions which deprive PEs of resources (Teske \& Schneider, 1994).

Resources are opportunities for policy entrepreneurs to gain or maintain political power, command more resources, or increase professional reputation or career prospects. For example, PEs are more likely to emerge in jurisdictions with slack budgetary resources available for accomplishing a desired policy outcome (Schneider \& Teske, 1992); when a jurisdiction has a full-time, competitively elected mayor sensitive to a PE's efforts to demonstrate voter support for the PE's policy vision (Schneider \& Teske, 1993a; Teske and Schneider, 1993b); and when relevant local interest groups are influential, since these represent constituencies whose support a PE could leverage (Kalafatis \& Lemos, 2017; Schneider \& Teske, 1993a, 1993b). Hereafter, I describe resources and obstacles to entrepreneurship as favorable and unfavorable structural conditions.

\section{A threat-centered theory of policy entrepreneurship}

The Schneider and Teske framework rests on a political-economic foundation which views individuals as rational utility-maximizers. By contrast, a number of prominent theories of the policy process place greater emphasis on humans as boundedly rational; motivated by emotions, beliefs, and perceptions; and frequently cognitively biased (e.g., Jones \& McBeth, 2010; Sabatier, 1988; Zahariadis, 2007). I contend these claims should extend to policy entrepreneurs.

\footnotetext{
1 Kalatatis and Lemos (2017) also explore the role of jurisdictional fragmentation in catalyzing entrepreneurship, showing that PEs are more common in cities within polycentric urban systems.
} 
Scholarship around the Advocacy Coalition Framework (ACF) assumes that individuals engage in politics primarily to effectuate deeply held beliefs (Sabatier, 1988; Sabatier \& Jenkins-Smith, 1999). These beliefs encourage people to find allies who share their views and work alongside them to push for policy goals, battling against those with opposing aims (Sabatier \& Weible, 2007; Weible et al., 1999). Actors view the benefits of engaging as large because their belief-infused perceptual filters lead them to perceive opponents as powerful, untrustworthy, and malicious (Sabatier \& JenkinsSmith, 1999; Sabatier \& Weible, 2007). The need to prevent opponents from securing "evil" policies thus becomes urgent. The existence of this "devil shift" and its influence on decision-making has been empirically demonstrated in wide-ranging policy scholarship (e.g., Fischer et al., 2016; Katz, 2018; Kingiri, 2014; Leong, 2015; Vogeler \& Bandelow, 2018; McBeth et al., 2014; Gottlieb et al., 2018; Heikkila et al., 2014; Merry, 2015; Shanahan et al., 2013).

The divergences between the political-economic and belief-centered perspectives on decision-making mean that current theorizing about policy entrepreneurship is incomplete. A policy entrepreneur may emerge because she calculates that the benefits of advocacy exceed the costs, but that calculus may be substantially shaped by her policy-relevant beliefs and a perceptual "devil shift"-with implications for when and where we should expect to find policy entrepreneurs operating. Conventional theorizing contends that PEs are unlikely to emerge where there is large or sustained opposition to their cause (Schneider et al., 1995; Teske \& Schneider, 1994; Kalatatis and Lemons, 2017), since opposition obstructs organizing or growing collective action; in such cases, PEs are expected to change venues to find a more receptive audience (Kingdon, 1984). I argue the contrary: Oppositional factors, by triggering a value-laden, devil shift-influenced fear of a threat to a desired policy goal, can catalyze policy entrepreneurship.

This catalysis is borne of policy beliefs and attendant devil shifts intertwining with loss aversion. Kahneman and Tversky's (1979) seminal argument that "losses loom larger than gains" suggests that the prospect of losing ground in a policy battle can propel individuals toward action to stave off the threat (see also Quattrone \& Tversky, 1988). This dynamic should be particularly likely when actors on either side of an issue have large, clear differences in policy-relevant beliefs and goals (Katz, 2018); when these faultlines elicit strong negative emotions often associated with greater demonization of the "other" (Alon and Omer, 2008; Fouts et al., 2006; Krumrei et al., 2011); and when an opponent's views pose a particular threat to an individual's identity, a condition that tends to increase conflict behaviors (Korostolina). Individuals facing an existential threat to a deeply held policy aim, and motivated to avoid a loss against opponents viewed as fearful and powerful, may jump into the policy fray because of, rather than despite, this opposition.

Other literature works lend support. Social psychology scholarship argues that crisesspecifically situations in which high-priority goals are threatened-can catalyze the emergence of charismatic leaders (Pillai, 1996; Pillai \& Meindl, 1991; Shamir \& Howell, 1999). By provoking emotional upheaval and stress, crises create conditions wherein members of a group or polity look for leaders to help protect or restore valued priorities (Boal \& Bryson, 1988; Lepsius, 1986). In parallel, crises can catalyze the emergence as leaders individuals who perceive a crisis as particularly urgent (Moerschell \& Lao, 2012) and have a particular high sense of self-efficacy, responsibility, or concern for others (Foti \& Hauenstein, 2006; Moerschell \& Lao, 2012; Se-Hyung, 2012). While the present paper does not explain who emerges as a policy entrepreneur, it coheres with this scholarship by arguing that perceptions of an urgent threat to valued goals, and associated intense emotions, can increase the likelihood of some individual stepping into this role. 
Additional support comes from scholarship on how grievances grow social movements, wherein actors jointly engage in political or cultural conflict based on a shared identity (Diani, 1992). Grievances framed as losses tend to engender strong emotions and greater willingness to participate in social movements (Bergstrand, 2014; Simmons, 2014). Presumably, the factors that encourage people to participate in a social movement also encourage some to lead it. ${ }^{2}$ If those individuals pursue particular policy goals, they can be considered policy entrepreneurs (Mintrom \& Norman, 2009). Thus, to the extent that activism from opponents is perceived as threatening the loss of a desired policy situation, we might expect an opposing policy entrepreneur to be particularly likely to emerge.

I pose three hypotheses. The first two are drawn from the conventional political-economic approach to PE emergence and the third derives from my threat-centered emergence theory. I anticipate that the threat of a policy loss may offer as much or greater explanation than the first two propositions for why entrepreneurial actors emerge to engage in policy conflict.

H1 Policy entrepreneurs are more likely to emerge in contexts where structural conditions are favorable for advocacy.

H2 Policy entrepreneurs are less likely to emerge in contexts where structural conditions are unfavorable for advocacy.

H3 Policy entrepreneurs are more likely to emerge in contexts where a policy loss appears more likely.

\section{Methods}

\section{The case}

I examine emergence of policy entrepreneurship in opposition or support of fracking in localities in the State of New York. Fracking is an oil and gas drilling technique that has transformed the U.S. energy industry by allowing the recovery of hydrocarbons from expansive underground shale formations. In the late 2000s, New York was poised to become ground zero for the nation's fracking boom, sitting atop more than 20,000 square miles of the Marcellus Shale, the world's largest unconventional natural gas reserve (Pierce et al., 2011). Fracking was expected to yield more than 54,000 jobs in New York over 30 years, increasing public revenues by \$32-126 million annually (Rugh, 2012). But despite these potential benefits, in 2008, New York placed a moratorium on fracking, motivated by concerns over adverse impacts on health, the environment, infrastructure, and communities (DeWitt, 2013).

The moratorium was intended to give state regulators time to tailor regulations to new issues raised by fracking (Executive Order, 41, 2010). That process, however, quickly became fraught and attenuated (Arnold et al., 2017), mirroring the near-deadlock between New York residents who supported versus opposed fracking (Quinnipaic University,

\footnotetext{
${ }^{2}$ Leadership in social movements is generally understudied owing to the structuralist bent in relevant scholarship (Ganz, 2010).
} 
2012). ${ }^{3}$ The moratorium lasted seven years, finally ending in December 2014 with a statewide ban. As it dragged on, anti- and pro-fracking advocates frustrated in their attempts to influence the state's opaque regulatory process shifted their efforts to localities (Arnold et al., 2017; Walsh et al., 2015). Between 2008 and 2012, 235 cities, villages, and towns in New York passed 358 moratoria, bans, zoning revisions, and resolutions. Nearly 50 adopted resolutions expressing support for fracking or encouraging the state to lift its moratorium. Moratoriums prohibited fracking locally for periods that varied between three months and multiple years, bans preventive fracking entirely, zoning policies restricted fracking to certain locations (e.g., areas designated for heavy industry, or beyond setbacks buffering schools or other public facilities), and resolutions sought to communicate local policy preferences to state policymakers and thereby influence their choices (Arnold and Nguyen Long, 2018). ${ }^{4}$ Policy entrepreneurs were key drivers behind this wave of local policymaking and the local contention that it both bred and fed (Arnold, 2020; Arnold et al., 2017).

Policy entrepreneurship around fracking in New York localities constitutes a crucial case (Gerring, 2007), one in which we should observe policy entrepreneurs emerging in response to signals of a looming policy loss, and if we do not, we should have serious doubts about the validity of this paper's central argument (Eckstein, 1975). At the time, fracking was a deeply controversial issue in New York. Critics held it would poison water and air and ruin the landscape, while supporters downplayed these concerns and argued that fracking could be an economic lifeline for struggling rural communities (Arnold et al., 2017; Dodge \& Lee, 2017; Nguyen Long et al., 2019). More than 200 anti-fracking groups sprung up across the state (NYAF, 2013), as did pro-fracking groups founded by landowners who had signed or wanted to sign leases for drilling (Esch, 2013; Jacquet \& Stedman, 2011). Fiery debate over fracking created "divisions between residents, residents and farmers, [and] farmers and other landowners... [that] threaten[ed] to tear apart the communit[ies]" (Crean, 2013).

This is the type of affect-laden, high-issue saliency setting in which policy scholars would expect to find deeply held policy beliefs driving people to join coalitions to advocate for their policy positions. Indeed, scholars have documented the devil shift in local debates over fracking governance in New York (Gottlieb et al., 2018). We might reasonably assume this shift leads people to view a policy loss as unacceptable and pushes people to participate in social movements. It is thus precisely the type of setting wherein signals that a policy loss is imminent should catalyze emergence of a policy entrepreneur seeking to stave off that loss.

\section{Survey administration}

In Summer 2014, I administered a 40-item postal survey to clerks in all New York municipalities $(n=1539)$ except New York City. ${ }^{5}$ The survey investigated local policymaking

\footnotetext{
3 This deadlock, in turn, was representative of the split in public opinion across the USA as a whole (Gerlach, 2015).

4 I consider resolutions alongside measures with more regulatory "teeth" because resolutions were used as policy instrument providing (political) information (Howlett and Raynor, 2007).

5 Villages were excluded if they were dissolved, or a decision was made to dissolve them, before or during the study period. New York City was omitted because, as a major international city, its characteristics and decisions arguably are not comparable with those of other municipalities. A handful towns and villages were treated as one unit because they are administered jointly.
} 
about fracking and elicited information about anti- and pro-fracking policy entrepreneurs. Municipal clerks were targeted as survey respondents because they take minutes at public meetings and are involved in many aspects of local government and thus are positioned to know about local political affairs (Arnold, 2020; Arnold et al., 2017; Kalafatis and Carmen Lemos, 2017; Kim, 1996; Schneider \& Teske, 1992, 1993a, 1993b; Teske \& Schneider, 1994). Survey administration followed Dillman's Tailored Design Method (Dillman et al., 2014) and yielded a $31 \%$ response rate.

Supplemental Information Table A1 reports t tests evaluating differences in means of potential covariates of survey response between responding and non-responding municipalities. Response was less likely in cities and more likely in less dense (presumably rural) municipalities where citizens voted at lower rates for President Obama. Responding municipalities had slightly smaller numbers of oily/gaseous spills in the ten years prior to the study period.

\section{Policy entrepreneur identification}

Survey respondents were asked to describe, if present, "one person who has tried to get your municipality to pass resolutions or policies opposing shale drilling" and, if present, one person who advocated for measures supporting shale drilling (fracking). ${ }^{6}$ Respondents were instructed that they could leave either the oppositional or supportive response line blank if no one in the municipality pursued oppositional/supportive activities, and that if more than one person did so, they should write the name of the "most active" opponent or proponent. ${ }^{7}$ Survey respondents in 71 jurisdictions (roughly $15 \%$ of the sample) identified an anti-fracking policy entrepreneur operating locally, 2008-2012. Thirty-seven (nearly $8 \%$ ) reported pro-fracking policy entrepreneurs active over the same period. Survey

\footnotetext{
6 To reach this question, respondents had to first affirm that there had been some level of public or political attention to fracking in their community, thereby making it plausible that someone there might have tried to get decision-makers to adopt fracking measures. It is possible that relying on clerks' recollection of policy debates in their municipality could lead to an underestimation of the number of policy entrepreneurs and their behaviors, particularly if PEs did not engage local government directly, but rather sought to influence policy through more arm's-length mechanisms such as writing a letter to a newspaper. There are three reasons to be confident that survey respondents provided reasonably accurate data. First, the survey was administered during a contentious electoral primary in which Gov. Andrew Cuomo was challenged for the Democratic gubernatorial nomination by a candidate who vociferously opposed fracking and won about one-third of the vote (Kaplan, 2014). Second, by the time the survey was administered, more than 16 percent of local jurisdictions in New York had adopted pro-or anti-fracking policies, and others had considered but failed to do so (Arnold and Nguyen Long, 2018). Because fracking was such a high-profile, salient issue at the state and local level, I expect that clerks were aware of local policy debates and policymaking on the topic. Third, in previous work, we asked New York municipal clerks to report the level of success fracking PEs experienced in their jurisdiction on a 1 (low) to 3 (high) scale then correlated these ratings with whether the jurisdiction had actually adopted a policy consistent with the PE's preferences; Spearman's rho was $0.66(p \leq 0.00, n=55)$ for anti-fracking PEs and $0.72(p \leq 0.00, n=28)$ for pro-fracking PEs (REDACTED). The fact that clerks' perception of PE efficacy compared favorably with objective policy data suggests that clerks are reasonably reliable informants.

7 This phrasing reflected the highly contentious policy environment around fracking, where participants overwhelmingly fell into two camps: oppose or support. Future research should examine whether threatdrive PE emergence occurs in less polarized contexts.
} 
Table 1 Descriptive statistics for policy entrepreneur archetypes

\begin{tabular}{|c|c|c|c|c|c|}
\hline & \multicolumn{2}{|c|}{ Less engaged, $N=33$} & \multicolumn{2}{|c|}{ More engaged, $N=38$} & \multirow[b]{2}{*}{$\begin{array}{l}\text { Significance } \\
\text { of difference }\end{array}$} \\
\hline & Mean & $\begin{array}{l}\text { Standard } \\
\text { deviation }\end{array}$ & Mean & $\begin{array}{l}\text { Standard } \\
\text { deviation }\end{array}$ & \\
\hline \multicolumn{6}{|l|}{ Anti-fracking policy entrepreneur } \\
\hline Total number of characteristics & 4.30 & 2.53 & 5.45 & 2.38 & $*$ \\
\hline Total number of strategies & 2.09 & 1.28 & 5.50 & 1.93 & $*$ \\
\hline \multirow[t]{2}{*}{ Total number of goals } & 2.15 & 1.09 & 3.95 & 1.92 & $*$ \\
\hline & \multicolumn{2}{|c|}{ Less engaged, $N=27$} & \multicolumn{2}{|c|}{ More engaged, $N=10$} & \\
\hline \multicolumn{6}{|l|}{ Pro-fracking policy entrepreneur } \\
\hline Total number of characteristics & 4.11 & 1.78 & 7.20 & 2.44 & $*$ \\
\hline Total number of strategies & 1.48 & 1.05 & 5.20 & 1.75 & $*$ \\
\hline Total number of goals & 1.11 & 0.93 & 1.40 & 1.07 & \\
\hline
\end{tabular}

One-tailed $t$ tests (unpaired data, unequal variance assumed) of null hypothesis that means are equivalent: $* p<0.05$

respondents were specifically asked to indicate the years (pre-2008, 2008, 2009, 2010, 2011, and 2012) in which the PEs they reported were active in their jurisdiction. ${ }^{8}$

The elicitation approach is similar to the Schneider and Teske's (1992, 743; 1993a, 1993b) tactic of asking the municipal clerk whether "during the past several years there had been anyone in their community whose "policy proposals represented a dynamic change in existing procedures"' (see also Teske \& Schneider, 1994; Arnold et al., 2017; Arnold, 2020). This understanding of policy entrepreneurship focuses on efforts by entrepreneurs to achieve specific local policies and excludes advocacy pursued in the community (e.g., forming a coalition) unless the entrepreneur did this as part of an effort to influence local policy.

This approach intentionally sets a low bar for classifying an individual as a policy entrepreneur; a clerk respondent simply must perceive that the individual engaged in advocacy. The threshold is low in order to capture policy entrepreneurs who might not have been particularly successful, since their attempt to change policy, rather than their skill at doing so, defines them as a PE (Arnold, 2020; Boasson \& Wettestad, 2014; Mintrom, 1997). However, I also consider an operationalization of policy entrepreneurship that relies on a higher threshold ("more engaged" PEs; see Table 1) and obtain similar results.

Because not all policy entrepreneurs seek the same goals or behave similarly, I use hierarchical cluster analysis (HCA) to identify policy entrepreneur archetypes differentiated by intensity and breadth of advocacy (Arnold, 2020). The HCA, described in detail the Supplemental Information, considers data from survey questions which asked respondents about the characteristics, strategies, and goals of the identified opponent and/or proponent. Two distinct anti-fracking PE and pro-fracking PE archetypes emerged from the HCA;

\footnotetext{
${ }^{8}$ Policy entrepreneurs are known for their tenacity, with advocacy sometime spanning years or even decades (Mintrom, 2019; Stone, 2019). However, scholars have also observed PEs suddenly emerging and acting rapidly and opportunistically (Boasson and Wettestad, 2014; Kingdon, 1984; Weissert, 1991). For this reason, and because fracking had only been on the policy agenda since the mid- to late-2000s, I consider as policy entrepreneurs individuals engage in advocacy over any portion of the study period, 2008-2012.
} 
they are labeled "less engaged" and "more engaged" in Table 1. Thirty-eight anti-fracking policy entrepreneurs and 10 pro-fracking PEs fall into the "more engaged" category. More engaged anti-fracking PEs had on average five entrepreneurial characteristics, used between four and five different strategies, and sought nearly four different policy goals. The average highly engaged pro-fracking PE had more than seven entrepreneurial characteristics, deployed more than four strategies, and sought one policy goal.

Separately analyzing "more engaged" policy entrepreneurs not only reduces the likelihood of conflating more run-of-the-mill pressure group participants with truly entrepreneurial actors, but also helps address potential survey priming concerns. It is possible that by identifying a PE on one side of the issue, a survey respondent was to identify an entrepreneur on the opposing side. The fact that more respondents reported a policy entrepreneur on only one side of the issue (40 municipalities) than reported two opposed PEs (34 municipalities) suggests that the majority of respondents were not swayed by a priming effect. Moreover, a respondent who nominates a fracking proponent primarily due to the priming effect of previously nominating an opponent would be unlikely to be able report many details about that proponent's behaviors; this "primed PE" would thus likely fall into the "less engaged" category. The danger in this approach is that it assumes that individuals for whom respondents report less intense advocacy are mistakes included in the data because of priming, when in reality they may simply have a less engaged advocacy style. Therefore, I model both the emergence of all reported PEs and those categorized as "more engaged."

\section{Analytical approach}

The study period begins in 2008, when the first New York municipalities adopted fracking measures, and ends after 2012, when the rate of passage of such policies substantially slowed (Arnold and Nguyen, 2018; Dokshin, 2016). I use multivariate logistic regression to predict the emergence of anti-fracking PEs in New York municipalities in 2009, 2010, 2011, and 2012 and predict the emergence of pro-fracking PEs in 2010, 2011, and 2012. ${ }^{9}$ The models include as predictors factors present in one or more prior years which could signal a looming policy loss and thus catalyze the emergence of a PE in the focal year. For example, in Fig. 1, the emergence of an anti-fracking PE in 2009 is modeled as a function of advocacy by a pro-fracking policy entrepreneur in 2008 (among other variables). The models also include variables measuring favorable or unfavorable structural conditions in one or more prior year(s).

All models penalize the likelihood function by the square root of the determinant of the information matrix so as to reduce small-sample bias (Lee, 2019). The analyses considering only "more engaged" policy entrepreneurs only model the emergence of anti-fracking PEs due to the small number of "more engaged" pro-fracking PEs in any given year.

\section{Independent variables}

H1 and H2 concern local structural conditions (Schneider and Teske's resources and obstacles) that favor or disfavor a would-be policy entrepreneur. Favorable structural conditions

\footnotetext{
9 I do not model pro-fracking PE emergence in 2009 due to the small number of pro-fracking PEs documented in 2008 .
} 


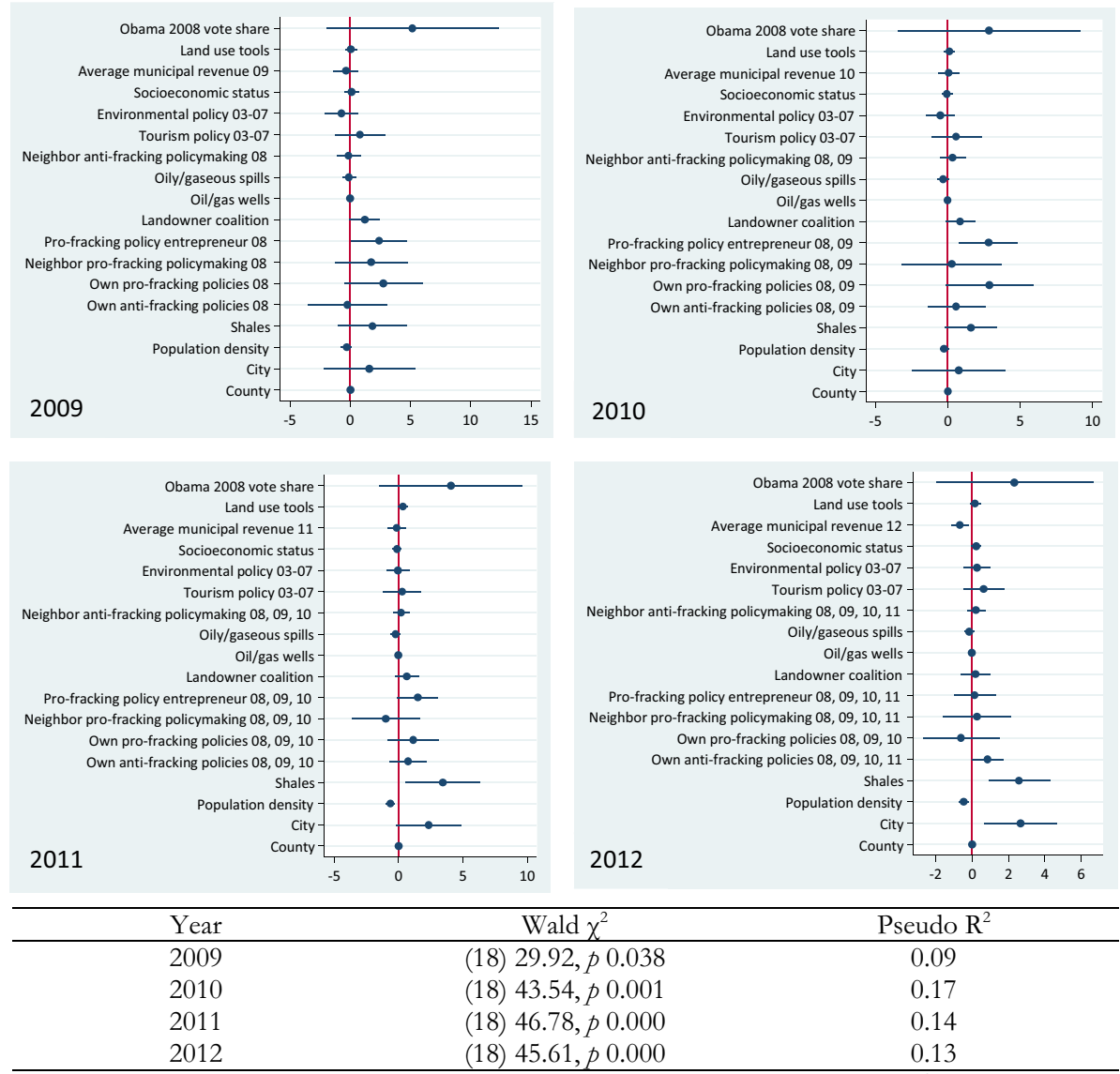

Notes: $\mathrm{N}=476$. Constants omitted, $95 \%$ confidence intervals, two-tailed. Pseudo $\mathrm{R}^{2}$ is the square of the correlation between observed and predicted values.

Fig. 1 Models predicting emergence of anti-fracking policy entrepreneurs annually, 2009-2012

offer wells of constituent or electoral support for a PE's advocacy or affect the extent to which a PE could successfully prosecute a policy goal if given the opportunity (e.g., a large budget for a city's parks department would be useful to a policy entrepreneur seeking to increase outdoor recreational programming). Structural conditions can be manipulated or leveraged by political actors but do not independently drive action (see De Havens, 1998). Unfavorable structural conditions reduce constituent or electoral support for advocacy or stand to hinder a PE's successful prosecution of her aims. Table 2 describes these structural conditions and whom they favor or disfavor. 


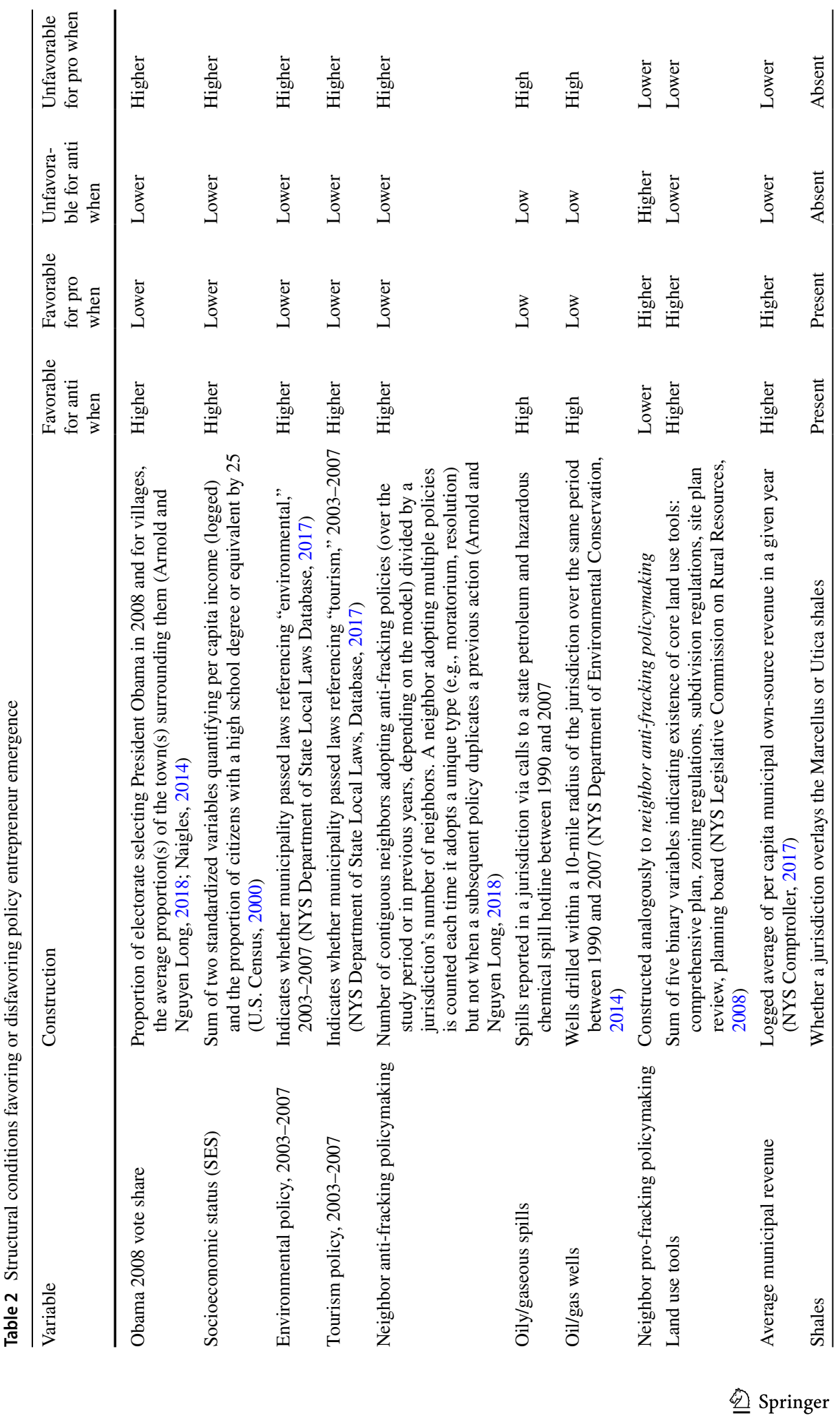




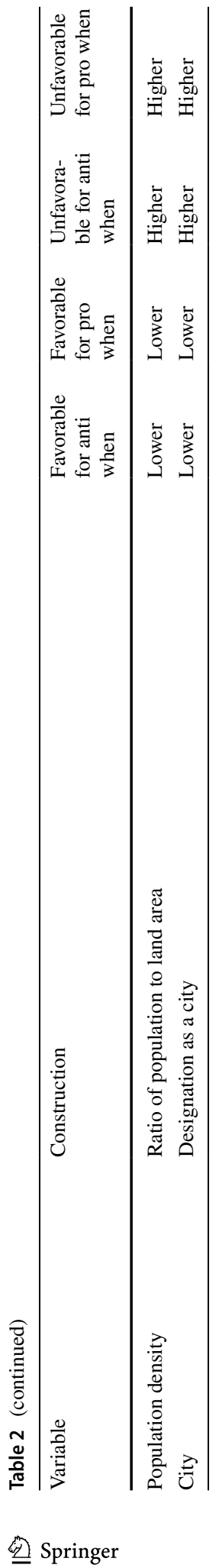


To elaborate: More liberal, ${ }^{10}$ educated, wealthier ${ }^{11}$ people tend to support environmentally protective policies (Krause, 2011; Sharp et al., 2011) and thus would offer a supportive constituency for a would-be anti-fracking policy entrepreneur but hinder a pro-fracking PE. The prior adoption of local environmental laws indicates presence of constituencies whose support for environmental protection or local amenities could motivate or be leveraged by an anti-fracking PE, but which could stymie a fracking advocate. When one or more neighboring jurisdictions adopt a fracking policy consistent with a PE's own preferences, this can offer her useful, context-appropriate policy examples and evidence of public support; however, her advocacy could be hindered if one or more neighbors adopt a policy opposite her preferences and thereby suggests that her position is unpopular. The extent of previous drilling and oil and gas spills ${ }^{12}$ in a jurisdiction favors anti-fracking policy entrepreneurs to the extent negative past experiences sour the public on the practice, and negative public opinion could be a liability for a pro-fracking PE trying to foster support for drilling.

Both anti- and pro-fracking PEs should be favored by the presence of more local land use infrastructure, offering more tools for advocacy and by greater municipal revenue, since wealthier municipalities likely have more resources to devote to a PE's cause (Schneider \& Teske, 1992, 1993b). Emergence of both types of PEs also should be favored when a jurisdiction is located over a shale and in a low-density rural area where fracking is more likely to occur, making the issue locally salient (Dokshin, 2016; Walsh et al., 2015). Finally, urban areas are less likely to have fracking and thus may be less likely to see emergence of either type of PE. ${ }^{13}$

$\mathrm{H} 3$ expects the threat of a looming policy loss will catalyze the emergence of a policy entrepreneur. Loss potential is signaled by presence in one or more prior years of an adversary entrepreneur actively working to achieve an opposing policy reality, and by the jurisdiction previously adopting policies opposite a PE's goals. A jurisdiction that previously adopted pro-fracking policy likely has a constituency that supports fracking-favorable action and could encourage additional such action. This threat could activate an antifracking PE to join the policy fray, trying to stave off more losses. I also expect the reverse: Prior anti-fracking policymaking should spur subsequent action from fracking proponents. Finally, the presence of a landowner coalition signals a potential loss for an anti-fracking PE because landowner groups support and lobby for fracking (Jacquet \& Stedman, 2011). ${ }^{14}$ These dynamics are summarized in Table 3.

\footnotetext{
10 Because national partisan political preferences do not always map to state dynamics, I reran the models presented in Figs. 1 and 2, replacing Obama vote share with the proportion of the jurisdiction's vote secured by the 2006 Democratic gubernatorial candidate. Results are equivalent except when predicting pro-fracking PE emergence in 2011; partisanship is no longer statistically significant when the gubernatorial voting measures used.

11 The components of the summative variable are strongly correlated, $\sigma=0.531(p \leq 0.00)$.

12 Spills whose description in a state database used one or more of the keywords: crude, diesel, gas, gasoline, grease, greasy, natural gas, oil, oily, petroleum.

13 The models also include a variable capturing county-specific favorable or unfavorable structural conditions. Multilevel specifications with jurisdictions nested in counties (county random effects) yielded similar results. However, across all seven multilevel specification, either a likelihood ratio test could not reject the null hypothesis of equivalence with a single-level model, $p<0.05$, or produced a $\chi^{2}$ test statistic of 0.0 . Thus, a single-level approach with county dummies is used for simplicity.

14 There is no centralized or comprehensive directory of coalitions. They were identified via an online directory from the Tioga County Landowners Group, the most extensive of all such listings found by
} 
Table 3 Signals of looming policy loss

\begin{tabular}{lll}
\hline $\begin{array}{l}\text { Variable: Presence in one or more } \\
\text { prior years of... }\end{array}$ & $\begin{array}{l}\text { Threatens a loss } \\
\text { for anti }\end{array}$ & $\begin{array}{l}\text { Threatens a } \\
\text { loss for pro }\end{array}$ \\
\hline $\begin{array}{l}\text { Anti-fracking PE } \\
\text { Pro-fracking PE }\end{array}$ & $\mathrm{X}$ \\
$\begin{array}{l}\text { Own anti-fracking policymaking } \\
\text { Own pro-fracking policymaking }\end{array}$ & $\mathrm{X}$ & $\mathrm{X}$ \\
Landowner coalition & $\mathrm{X}$ & \\
\hline
\end{tabular}

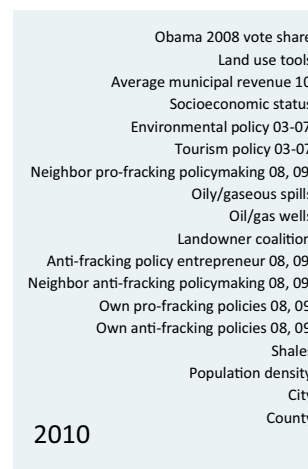

2012

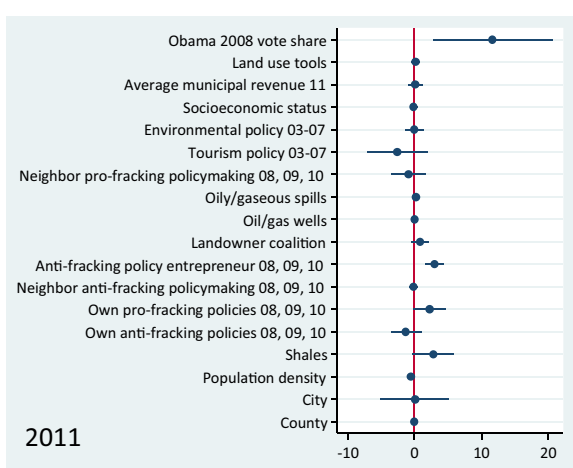

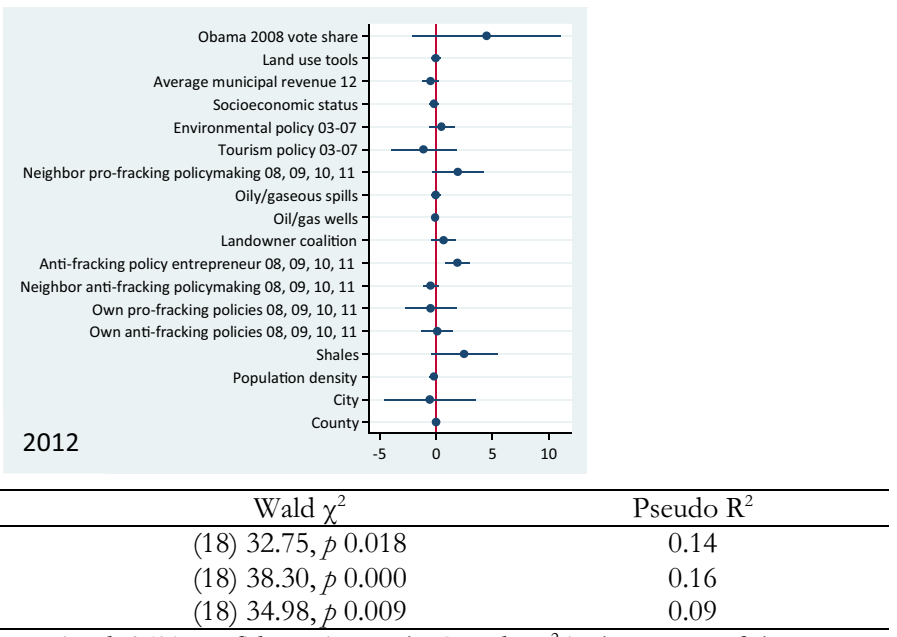

Notes: $\mathrm{N}=476$. Constants omitted, $95 \%$ confidence intervals. Pseudo $\mathrm{R}^{2}$ is the square of the correlation between observed and predicted values.

Fig. 2 Models predicting emergence of pro-fracking policy entrepreneurs annually, 2010-2012

Footnote 14 (Continued)

Nguyen Long and Arnold (2018). Coalitions lacking an independent online presence or advertising services outside New York were excluded. The Tioga County Landowners Group directory did not indicate coalition formation dates. The annual anti-fracking PE models include landowner coalition even though this variable is measured across the entire study period. There is some reason to suspect that many coalitions formed in 2008 and thus using them to predict PE emergence in subsequent years may not be inappropriate. Jacquet and Stedman (2011) interviewed coalition representatives in southern New York and found that 7 of 9 were formed in 2008 ( 2 were formed in 2009 and 2010, respectively). To the extent that this sample is representative, we might assume that many coalitions statewide formed in 2008 . 


\section{Analysis}

Figures 1 and 2 plot coefficients from annual models predicting emergence of anti- and pro-fracking PEs. Despite expectations in $\mathrm{H} 1$ and $\mathrm{H} 2$, structural conditions generally did not predict PE emergence. Two conditions were statistically significant in unexpected directions: In 2012, the likelihood of the most poorly resourced municipality experiencing the emergence of anti-fracking PE appears nearly 50 percentage points greater than the likelihood of the wealthiest municipality doing so. ${ }^{15}$ And in 2011 , the most liberal polity was more than 42 percentage points more likely to see the emergence of a pro-fracking PE than the most conservative polity.

Consistent with H3, the presence of an opposing policy entrepreneur-whose advocacy represents a tangible threat of policy loss ${ }^{16}$ - offers substantial explanatory leverage across most models. In 2009 and 2010, and marginally in $2011(p=0.062)$, the presence of a fracking proponent in one or more prior years significantly predicts the emergence of an anti-fracking policy entrepreneur in the focal year. Prior presence of a pro-fracking PE yields a roughly 19 percentage-point bump in anti-PE emergence likelihood in 2009; in 2010, 33 points; and in 2011, 13 points. The prior presence of an anti-fracking PE also statistically significantly predicts emergence of a pro-fracking advocate in all three years examined. In 2010, the prior presence of an anti-fracking PE predicts a nearly 14 percentage point increase in the likelihood of a pro-fracking PE emerging; in 2011, 21 points; and in 2012,14 points.

The models in Fig. 3 predict the emergence of "more engaged" anti-fracking policy entrepreneurs. Again, most structural conditions are not predictive, with a few exceptions. In 2011, a polity at the maximum value for liberalism was about 20 percentage points more likely to see the emergence of a highly engaged anti-fracking PE than one at the lowest value $(p=0.059)$, an effect that rises to 25 percentage points in 2012. There is also an unexpected dynamic in 2012 wherein the poorest jurisdiction appears about 46 percentage points more likely to see the emergence of a highly engaged anti-fracking PE than the wealthiest jurisdiction.

H3 again finds support in these models. The presence of a "more engaged" pro-fracking policy entrepreneur in one or more prior years increased the predicted likelihood of a "more engaged" anti-fracking PE emerging in 2010 by 49 percentage points; in 2011, 35 points; and in 2012, 15 points. ${ }^{17}$ In 2009 and 2010, the presence of a landowner coalition is predicted to increase the likelihood of a "more engaged" anti-fracking PE emerging by roughly 7 percentage points. ${ }^{18} \mathrm{~A}$ jurisdiction's own prior oppositional policymaking appeared to have no catalyzing effect.

I pursue two robustness checks. First, because some variables signaling policy loss for fracking opponents (landowner coalition, pro-fracking PE presence, and own prior profracking policies) are correlated above 0.5 (see SI Tables A4-A7), I use likelihood ratio (LR) tests to evaluate their equivalence in models of anti-fracking PE emergence. The tests cannot reject the null of equivalence. The take-away is that these signals of potential policy

\footnotetext{
15 In this calculation and all likelihood predictions, all other variables are set at their means.

16 Another loss signal operated as expected in 2012, when a jurisdiction's own prior adoption of an antifracking policy increases the estimated likelihood of an anti-fracking PE emerging by nearly 9 percentage points $(p=0.051)$.

17 Coefficient in 2012 marginally statistically significant, $p=0.059$.

18 Coefficient in 2010 marginally statistically significant, $p=0.054$.
} 


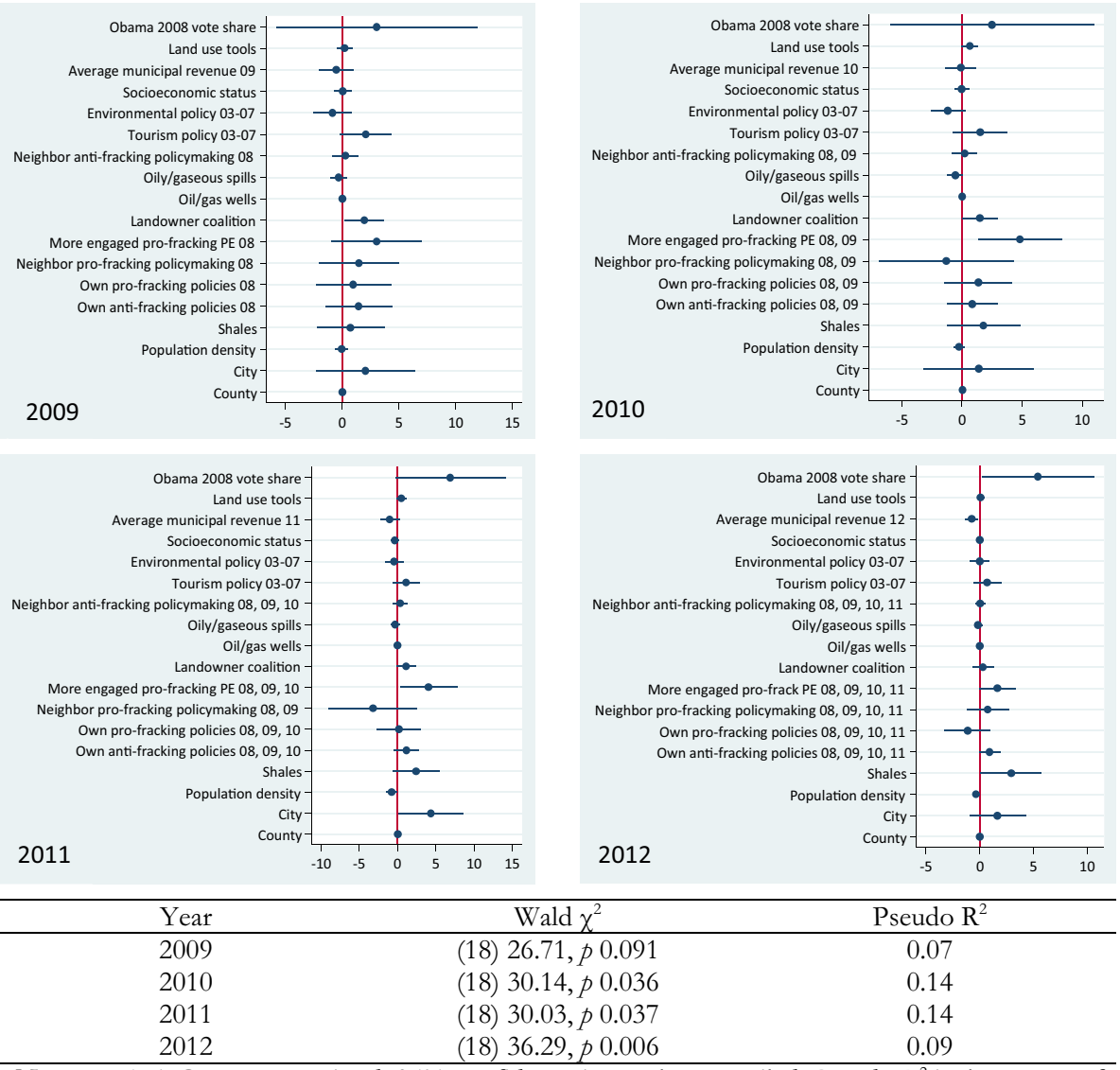

Notes: $\mathrm{N}=476$. Constants omitted, $95 \%$ confidence intervals, two-tailed. Pseudo $\mathrm{R}^{2}$ is the square of the correlation between observed and predicted values.

Fig. 3 Models predicting emergence of "more engaged" anti-fracking policy entrepreneurs annually, 20092012

loss matter for catalyzing entrepreneurial opposition, but we cannot isolate their independent effects.

In the models of pro-fracking PE emergence, LR tests reject the null of equivalence between the two policy loss-associated predictors correlated above 0.5 (anti-fracking PE and own anti-fracking policies) in 2011 and 2012, but not 2010; see SI Table A8. Of these two correlated variables, only presence of a fracking opponent appears to significantly predict pro-fracking PE emergence. Advocacy by a specific opponent thus appears a distinct and impactful catalyst for pro-fracking advocates.

Second, since the loss-signifying factors appear statistically equivalent in the anti-fracking models, I re-run those models, replacing the correlated predictors with a loss threat index. This index ranges from 0 to 3 , summing three binary variables: Whether a jurisdiction previously adopted a pro-fracking policy, had a pro-fracking PE, or had a landowner coalition; see SI Figure A9. Consistent with the main findings, loss-threatening factors as a group predict and potentially catalyze PE emergence in three of the four models. 


\section{Discussion and conclusion}

In battles over local government policymaking, the salient threat of a potential policy loss appears to catalyze the emergence of a policy entrepreneur with opposing aims. This effect is consistent across most models of both pro- and anti-fracking PE emergence. Conventional theorizing about and empirical research on policy entrepreneurship emphasizes the pull of resource available for advocacy and pushback from obstacles, yet in this analysis, such structural conditions offer relatively little consistent explanatory leverage. What causes this divergence?

One possibility is simply omitted variable bias: past research on policy entrepreneur emergence did not conceptualize or measure it as a phenomenon arising in response to advocacy from an opposing political actor. Another possibility is that the catalysts and nature of policy entrepreneurship concerning a hotly contested, politicized issue linked to broad societal cleavages (e.g., liberalism vs. conservatism, environmental protection vs. economic growth) is fundamentally different than the policy entrepreneurship previously explained within the traditional political-economic framework. Work by Schneider and Teske, for example, focused on elected municipal leaders and unelected administrators promoting innovations in local government generally and pro- and anti-economic growth policies specifically. ${ }^{19}$ In the former studies, the nature of the policy innovations is barely discussed; some may have been neither widely controversial nor widely publicly observable. In the latter, the interests and actors shaping local economic growth trajectories are often concentrated or elite: local government itself, public-private organizations, or private sector organizations such as a chamber of commerce or industry group (Hammer \& Green, 1996).

This is consequential because organizing around fracking's regulation in New York in the late 2000s and early 2010s looked quite different; it commanded widespread and intense public attention from participants who often viewed the debate over fracking as zero-sum, a war between "Drill, Baby, Drill" and "No Fracking Way" (see Gottlieb et al., 2018). As a societal movement, environmental advocacy traditionally involves grassroots organizing, explicit attempts to garner public support and build coalitions, and diverse participants (Johnson, 2008; Silveira, 2000). Although less work has characterized the "YIMBY" movement (Yes In My Backyard), Jacquet and Stedman (2011) identify at least 35 grassroots landowner coalitions operating in the shale-rich portion of New York in the late 2000s, seeking to encourage fracking and boasting hundreds and in some cases thousands of member households. It is also worth pondering whether threat-centered policy entrepreneur emergence is linked to the increasing partisan polarization and "social tribalism" in American politics (see Lubell, 2013), which certainly was occurring during the study period and with respect to fracking (Veenstra et al., 2016).

In other words, the present results may differ from prior ones because of key differences in both the entrepreneurs and their worlds of action. Officials within government, tackling issues which may be relatively uncontroversial or unconnected to broad sociopolitical movements or identities, may not be driven by passion to effectuate a singular policy belief into policy. They may engage in entrepreneurism to change governmental procedures due to public service motivation (e.g., Perry, 1997), professionalism (e.g., Lewis and Ramakrishnan, 2007), or professional ambition (e.g., Teodoro, 2011), none of which necessarily

\footnotetext{
19 Kalafatis and Lemos (2017) do not provide occupational details for the PEs they identify except that they operated "inside or outside government."
} 
involve advocating for policy out of fear over losing a desired policy situation to malicious opponents. By contrast, individuals who may or may not hold a government position, ${ }^{20}$ concerned about an existential, zero-sum threat to their livelihoods, identities, or values, possessing strong beliefs about how that threat should be addressed, and buttressed by a range of peers and social connections sharing their beliefs, may indeed by catalyzed to entrepreneurship when advocacy by an opponent makes a policy loss appear more likely. The material resources available to put an innovation into practice in government may be a key incentive for the former, whereas emotion-laden rejection of an opponent's values may be key for the latter. The fact that both sets of individuals fit the broad definition of a PE underscores the importance of attending to PEs' goals, motivations, and context when trying to understand their emergence, behaviors, and outcomes. Future research should investigate the presence and extent of threat-centered PE emergence in policy debates with varying degrees of politicization, emotional affect, and technical complexity.

This case also draws attention to potentially productive engagement between scholarship on social movements and on policy entrepreneurship. Critics contend that social movement scholarship has devoted insufficient attention to how movement leaders emerge and operate, focusing more on structural conditions and group-level behavior (Ganz and McKenna, 2018). And despite emphasizing that policy entrepreneurs build coalitions and leverage network connections to achieve their goals (Frisch Aviram et al., 2020; Arnold, 2020; Mintrom \& Norman, 2009), policy entrepreneurship scholars rarely conceptualize PEs as leaders of social movements. ${ }^{21}$ There are reasons for them to be cautious-a social movement leader is not necessarily a policy entrepreneur, unless and until she engages the political process to achieve specific policy goals-but there clearly are linkages between these areas of study. Social movement scholars could benefit from policy scholars' insights about how, why, and when policy advocates emerge and act, while policy scholars could benefit from social movement scholars' insights about strategies used in social movements to press for change. This dialog should continue.

Like any study, the present research has limitations. Because it takes the traditional approach of focusing on single policy entrepreneurs, rather than collaborative entrepreneurship efforts, it may overlook an emergence driver specific to the latter; people might decide to join the entrepreneurial vanguard because their friends (or peers or mentors) are doing so. As is typical of research using survey data, the results may be affected by recall issues: The dependent variable relies on respondents' reports of the years in which policy entrepreneurs were active in their community, but their memories may be imprecise. The study examined roughly 100 policy entrepreneurs, all concerned with one issue, in a relatively short period of time, in one state. While this isomorphism facilitates large-n, crosssectional analysis, it begs the question of generalizability. Future research should evaluate the relative impact of resources, obstacles, and policy loss signals on PE emergence across a range of issues and contexts. Such research should move from analysis of "most likely" cases such as this one to harder tests. It should also survey or interview policy entrepreneurs themselves and directly ask them about their motivations, seeking to understand

\footnotetext{
${ }^{20}$ Survey respondents were able to provide occupational data for fewer than half of policy entrepreneurs they described, so I do not explicitly analyze occupation. The PEs for which respondents did report occupations spanned a range of occupational sectors, with no clear majority.

21 There are some exceptions. Rutledge (2012) argues that the Indian Supreme Court, acting as a policy entrepreneur, can make decisions that spur and provide favorable legal context for social movements. Lyon (2018) conceptualizes Pope Francis as a policy entrepreneur driving forward a global social movement to address climate change.
} 
whether and the extent to which they were motivated by a devil shift, fear of policy loss, and available resource or scouraged by obstacles. Such research should identify policy entrepreneurs using a variety of techniques (e.g., newspaper searches, key informant interviews), since municipal clerk survey respondents may not observe low-salience or unsuccessful policy entrepreneur activity.

Finally, a major hole in policy entrepreneurship scholarship is our inability to explain who emerges as a policy entrepreneur. The present study only identifies contextual factors affecting where and when PEs are more likely to emerge. But the supply of plausible candidates for entrepreneurship may matter as much, or more, than having the right contextual factors (c. f. Teodoro, 2011). Cross-sectional, large-n surveys of PEs, digging into their personal and professional characteristics and contexts, would be a good start. But even this effort would not get at why individuals possessing similar characteristics and backgrounds vary in their willingness to step up to advocacy. Scholarship on leadership generally and leadership in social movements specifically may offer theoretical insights, while empirical strides could be made by surveying communities where many members might have opinions about policies affecting their work or interests (e.g., teachers, doctors) but only some regularly engage in advocacy. Such efforts, alongside the present study, can help political scientists provide powerful insights into when, where, and how advocacy translates into policy change.

Supplementary Information The online version contains supplementary material available at https:/doi. org/10.1007/s11077-021-09445-z.

Acknowledgements I'm grateful for comments on this paper provided by participants in the International Workshop on Promoting Activism and Policy Entrepreneurship among Street-Level Bureaucrats, held in Haifa, Israel, in 2019 and organized by Drs. Nissen Cohen and Neomi Frisch-Aviram. Undergraduate student interns in the Center for Environmental Policy and Behavior at UC Davis are an invaluable help in data collection, organization, and analysis. Joy Jia, Nikita Sinha, and Michael Bybee in particular helped build the foundation of data upon which this paper is built.

Funding Funding was provided by National Science Foundation.

Open Access This article is licensed under a Creative Commons Attribution 4.0 International License, which permits use, sharing, adaptation, distribution and reproduction in any medium or format, as long as you give appropriate credit to the original author(s) and the source, provide a link to the Creative Commons licence, and indicate if changes were made. The images or other third party material in this article are included in the article's Creative Commons licence, unless indicated otherwise in a credit line to the material. If material is not included in the article's Creative Commons licence and your intended use is not permitted by statutory regulation or exceeds the permitted use, you will need to obtain permission directly from the copyright holder. To view a copy of this licence, visit http://creativecommons.org/licenses/by/4.0/.

\section{References}

Alon, N., \& Omer, H. (2008). The psychology of demonization. Lawrence Erlbaum.

Anderson, S., DeLeo, R., \& Taylor, K. (2020). Policy entrepreneurs, legislators, and agenda setting. Policy Studies Journal, 43(3), 587-611.

Anderton, K., \& Setzer, J. (2018). Subnational climate entrepreneurship. Regional Environmental Change, $18,1273-1284$.

Arnold, G. (2020). Does entrepreneurship work? Understand what policy entrepreneurs do and whether it works. Policy Studies Journal, 8, 9. https://doi.org/10.1111/psj.12388

Arnold, G., \& Long, L. A. N. (2018). Policy expansion in local government environmental policymaking. Public Administration Review, 79(4), 465-476. 
Arnold, G., Long, L. A. N., \& Gottlieb, M. (2017). Social networks and policy entrepreneurship. Policy Studies Journal, 45(3), 414-441.

Arnold, G., \& Neupane, K. (2017). Determinants of pro-fracking measure adoption by New York Southern Tier municipalities. Review of Policy Research, 34(2), 208-232.

Bergstrand, K. (2014). The mobilizing power of grievances. Mobilization, 19(2), 123-142.

Boal, K., \& Bryson, J. (1988). Charismatic leadership: A phenomenological and structural approach. In J. Gerald Hunt, B. Rajaram Baliga, H. Peter Dachler, \& C. Schriesheim (Eds.), Emerging leadership vistas (pp. 11-28). Lexington.

Boasson, E., \& Wettestad, J. (2014). Policy invention and entrepreneurship. Global Environmental Change, 29, 404-412.

Brasil, F. G., \& Capella, A. C. N. (2017). Translation ideas into action: Brazilian studies of the role of the policy entrepreneur in the policy process. Policy and Society, 36(4), 504-522.

Cairney, P. (2018). Three habits of successful policy entrepreneurs. Policy and Politics, 46(2), 199-215.

Carter, N., \& Childs, M. (2018). Friends of the earth as a policy entrepreneur. Environmental Politics, 27(6), 994-1013.

Crean, S. (2013). The promised land: A small town's struggle with hydrofracking. Gotham Gazette (February 10). http://www.gothamgazette.com/index.php/environment/4164-the-promised-landa-smalltowns-struggle-with-hydrofracking. Accessed 2 August 2016.

Davis, C. (2012). The politics of "fracking" regulating natural gas drilling practices in Colorado and Texas. Review of Policy Research, 29(2), 177-191.

De Haven-Smith, L. (1998). Collective will formation: The missing dimension in public administration. Administrative Theory and Praxis, 20(2), 126-140.

DeWitt, K. (2013). New York fracking moratorium enters its 6th year. NCPR, July 24. https://www.north countrypublicradio.org/news/story/22414/20130724/ny-fracking-moratorium-enters-6th-year. Accessed 31 May 2020.

Diani, M. (1992). The concept of social movement. The Sociological Review, 40(1), 1-25.

Dillman, D., Smyth, J., \& Christian, L. (2014). Internet, phone, mail, and mixed-method surveys: the tailored design method. Wiley.

Dodge, J., \& Lee, J. (2017). Framing dynamics and political gridlock: The curious case of hydraulic fracturing in New York. Journal of Environmental Policy and Planning, 19(1), 14-34.

Dokshin, F. (2016). Whose backyard and what's at issue? Spatial and ideological dynamics of local opposition to fracking in New York State, 2010-2013. American Sociological Review, 81(5), 921-948.

Eckstein, H. (1975). Case studies and theory in political science. In F. I. Greenstein \& N. W. Polsby (Eds.), Handbook of political science. Political science: Scope and theory (Vol. 7, pp. 94-137). Addison-Wesley.

Esch, M. (2013). Many NY gas leases expire as moratorium remains. Observer Dispatch, May 13. http:// www.syracuse.com/news/index.ssf/2013/05/manynygasleasesexpireasm.html. Accessed 2 August 2016.

Farris, J. (2013). Demonizing the other: An analysis of moral conflict, violence, and spirituality. Journal of Spirituality and Mental Health, 15(4), 277-292.

Ferman, B., \& Levin, M. (1987). Dilemmas of innovation and accountability: Entrepreneurs and chief executives. Policy Studies Review, 7(1), 187-199.

Fischer, M., Ingold, K., Sciarini, P., \& Varone, F. (2016). Dealing with bad guys: Actor- and process-level determinants of the "devil shift" in policymaking. Journal of Public Policy, 36(2), 309-334.

Font, N., \& Subirats, J. (2010). Water management in Spain: The role of policy entrepreneurs in change. Ecology and Society, 15(2), 15.

Foti, R., \& Hauenstein, N. (2006). Pattern and variable approaches in leadership emergence and effectiveness. Journal of Applied Psychology, 92(2), 347-355.

Fouts, G., Callan, M., Plasentin, K., \& Lawson, A. (2006). Demonizing in children's television cartoons an animated films. Child Psychiatry and Human Development, 37, 15-23.

Frisch Aviram, N., Cohen, N., \& Beeri, I. (2020). Wind(ow) of change: A systematic review of policy entrepreneurship characteristics and strategies. Policy Studies Journal, 48, 612-644.

Ganz, M. (2010). Leading change: Leadership, organization, and social movements. In N. Nohria \& R. Khurana (Eds.), Handbook of leadership theory and practice (pp. 1-42). Harvard Business Press.

Ganz, M. \& McKenna, E. (2018). Bringing leadership back. In In D.A. Snow, S.A. Soule, H. Kriesi \& H.J. McCammon (Eds.), The Wiley blackwell companion to social movements

Gerlach, J. (2015). The tenuous place of environmental policy and national politics. Citizen Times, July 24. https://www.citizen-times.com/story/opinion/contributors/2015/07/24/tenuous-place-environmentalpolicy-national-politics/30622991/. Accessed 7 August 2021.

Gerring, J. (2007). Is there a (viable) crucial-case method? Comparative Political Studies., 40(3), 231-253. 
Gerry, J. (2007). Is there a viable (crucial) case method? Comparative Political Studies, 40(3), 231-253.

Gottlieb, M., Oeninger, E., \& Arnold, G. (2018). No fracking way" vs. "Drill baby drill. Policy Studies Journal, 46(4), 728-827.

Hammer, R., \& Green, G. (1996). Local growth promotion. Economic Development Quarterly, 10(4), 331-341.

Heikkila, T., Weible, C., \& Pierce, J. (2014). Exploring the policy narratives and politics of hydraulic fracturing in New York. In M. Jones, E. Shanahan, \& M. McBeth (Eds.), The science of stories (pp. 185-206). Palgrave Macmillan.

Howlett, M., \& Rayner, J. (2007). Design principles for policy mixes. Policy and Society, 26(4), 1-18.

Huitema, D., \& Meijerink, S. (2010). Realizing water transitions. Ecology and Society, 15(2), 26.

Jacquet, J., \& Stedman, R. (2011). Natural gas landowner coalitions in New York State. Journal of Rural Social Sciences, 26, 62-91.

Johnson, E. (2008). Social movement size, organizational diversity, and making of federal law. Social Forces, 86(3), 967-993.

Jones, M. D., \& McBeth, M. (2010). A narrative policy framework: Clear enough to be proven wrong? Policy Studies Journal, 38(2), 329-353.

Kahneman, A., \& Tversky, D. (1979). Prospect theory: An analysis of decision under risk. Econometrica, 47(2), 263-292.

Kalafatis, S., \& Lemos, M. C. (2017). The emergence of climate change policy entrepreneurs in urban regimes. Regional Environmental Change, 17(6), 1791-1799.

Kaplan, T. (2014). Citing health risks, Cuomo bans fracking in New York State. New York Times, Dec. 17. https://www.nytimes.com/2014/12/18/nyregion/cuomo-to-ban-fracking-in-new-york-state-citinghealth-risks.html. Accessed 7 August 2021.

Katz, J. (2018). The space between: Demonization of opponents and policy divergence. Review of Policy Research, 35(2), 280-301.

Kim, D. (1996). The emergence of policy entrepreneurs in local communities. Korean Review of Public Administration, 1(1), 291-314.

King, P., \& Roberts, N. (1992). An investigation into the personality profile of policy entrepreneurs. Public Productivity and Management Review, 6(2), 173-190.

Kingdon, J. W. (1984). Agendas, alternatives, and public policies. Little, Brown.

Kingri, A. N. (2014). Comparative strategic behavior of advocacy coalitions and policy brokers. Journal of Comparative Policy Analysis, 16(4), 373-395.

Kobrak, P. (1996). The social responsibilities of a public entrepreneur. Administration and Society, 28(2), 205-237.

Korostelina, K. (2006). Identity salience as a determinant of the perceptions of the other. In D. Rothbart \& K. Koroselina (Eds.), Identity, morality, and threat (pp. 101-128). Lexington.

Korostelina, K. (2007). Social identity and conflict. Palgrave.

Krause, R. (2011). Policy innovation, intergovernmental relations, and the adoption of climate protection initiatives by U.S. cities. Journal of Urban Affairs, 33(1), 45-60.

Krumrei, E., Mahoney, A., \& Pargament, K. (2011). Demonization of divorce. Family Relations, 60, 90-103.

Lee, S. (2019). Logistic regression procedure using penalized maximum likelihood estimation for differential item functioning. Journal of Educational Measurement (forthcoming).

Leong, C. (2015). Persistently biased: The devil shift in water privatization in Jakarta. Review of Policy Research, 32(5), 600-621.

Lepsius, M. R. (1986). Charismatic leadership. In C. F. Graumann \& S. Moscvici (Eds.), Changing conceptions of leadership (pp. 53-66). Springer.

Lewis, P., \& Karthick Ramakrishnan, S. (2007). Police practices in immigrant destination cities: Political control or bureaucratic professionalism. Urban Affairs Review, 42(6), 874-900.

Long, N., Ahn, Le., Foster, M., \& Arnold, G. (2019). The impact of stakeholder engagement on local policy decision-making. Policy Sciences, 52, 549-571.

Lopez, E. J. (2002). The legislator as political entrepreneur. Review of Austrian Economics, 15(2/3), 211-228.

Lubell, M. (2013). Governing institutional complexity. Policy Studies Journal, 41(3), 537-559.

Lyon, A. J. (2018). Pope Francis as a global policy entrepreneur. In A. J. Lyon, C. Gustafson, \& P. C. Manuel (Eds.), Pope Francis as a global actor (pp. 119-142). Palgrave.

Mack, W., Green, D., \& Vedlitz, A. (2008). Innovation and implementation in the public sector: An examination of public entrepreneurship. Review of Policy Research, 25, 233-252.

McBeth, M., Jones, M., \& Shanahan, E. (2014). The narrative policy framework. In P. Sabatier \& C. Weible (Eds.), Theories of the policy process (3rd ed., pp. 225-266). Westview. 
Merry, M. (2015). Constructing policy narratives in 140 characters or less: The case of gun policy organizations. Policy Studies Journal, 44(4), 373-395.

Mintrom, M. (1997). Policy entrepreneurs and the diffusion of innovation. American Journal of Political Science, 41(3), 738-770.

Mintrom, M. (2019). So you want to be a policy entrepreneur? Policy Design and Practice, 2(4), 307-323.

Mintrom, M., \& Norman, P. (2009). Policy entrepreneurship and policy change. Policy Studies Journal, 37(4), 649-667.

Mintrom, M., Salisbury, C., \& Luetjens, J. (2014). Policy entrepreneurs and promotion of Australian state knowledge economies. Australian Journal of Political Science, 49(3), 423-438.

Moerschell, L., \& Lao, T. (2012). Igniting the leadership spark: An exploration of decision-making and punctuated changed. Emergence: Complexity and Organizations, 14(2), 54-68.

Naigles, G. (2014). Collecting and analyzing the municipality-level results of the 2008 and 2012 presidential election in $N Y, P A$, and $O H$. Colby College (Unpublished manuscript).

New York State Legislative Commission on Rural Resources (NYSLCRR). (2008). New York land use tools. NYSLCRR.

New York Department of State (NYDOS). (2011). Local government handbook. NYDOS.

New Yorkers against fracking (NYAF). 2013. Facts. http://nyagainstfracking.org/facts/. Accessed 13 June 2013.

New York State Department of Environmental Conservation (NYSDEC). (2014). Downloadable well data. http://www.dec.ny.gov/energy/1603.html. Accessed 19 July 2017.

New York State (NYS) Comptroller. (2017). Financial data for local governments. https://osc.state.ny.us/ localgov/datanstat/findata/index_choice.htm. Accessed 17 June 2017.

Oliver, T. R., \& Paul-Shaheen, P. (1997). Translating ideas into actions: Entrepreneurial leadership in state health care reforms. Journal of Health Politics, Policy and Law, 22(3), 721-789.

Olson, M. (1965). The logic of collective action. Harvard.

Perry, J. (1997). Antecedents of public service motivation. Journal of Public Administration Research and Theory, 7(2), 181-197.

Pierce, B., Coleman, J., \& Demas, A. (2011). USGS releases new assessment of gas resources in the marcellus shale, appalachian basin. Reston, VA: U.S. Department of the Interior, U.S. Geological Survey.

Pillai, R. (1996). Crisis and the emergence of charismatic leadership in groups. Journal of Applied Social Psychology, 26(6), 543-562.

Pillai, R., \& Meindl, J. (1991). The effect of a crisis on the emergence of charismatic leadership. Academy of Management Proceedings, 51, 235-239.

Quattrone, G., \& Tversky, A. (1988). Contrasting rational and psychological analysis of political choice. American Political Science Review, 82, 719-736.

Quinnipaic University. (2012). Quinnipiac University Poll, New York State. http://www.quinnipiac.edu/ newsand-events/quinnipiac-university-poll/new-york-state/release-detail?ReleaseID51780. Accessed 10 January 2016.

Ramamurti, R. (1986). Public entrepreneurs: Who they are and how they operate. California Management Review XXVII (3). Spring.

Roberts, N., \& King, P. (1991). Policy entrepreneurs: Their structure and function in the policy process. Journal of Public Administration Research and Theory, 1(2), 147-175.

Rojo, L. M. (1995). Division and rejection: From the personification of the Gulf Conflict to the demonization of Saddam Hussein. Discourse and Society, 6(1), 49-80.

Rugh, P. (2012). As Cuomo weighs fracking, two small towns highlight the risks. The Examiner, May 2. http://www.examiner.com/article/as-cuomo-weighs-fracking-two-small-towns-highlight-the-risks. Accessed 14 November 2012.

Rutledge, J. G. (2012). Courts as entrepreneurs: The case of Indian mid-day meals programs. Asian Politics and Policy, 4(4), 527-547.

Sabatier, P. (1988). An advocacy coalition framework of policy change and the role of policy-oriented learning therein. Policy Sciences, 21(2-3), 129-168.

Sabatier, P., \& Jenkins-Smith, H. (1999). The advocacy coalition framework. In P. Sabatier (Ed.), Theories of the policy process (pp. 117-168). Westview.

Sabatier, P., \& Weible, C. (2007). The advocacy coalition framework. In P. Sabatier \& C. Weible (Eds.), Theories of the policy process (2nd ed., pp. 189-221). Westview.

Schneider, M., \& Teske, P. (1992). Toward a theory of the political entrepreneur. American Political Science Review, 86(3), 737-747.

Schneider, M., \& Teske, P. (1993a). The anti-growth entrepreneur. Journal of Politics, 55, 720-736.

Schneider, M., \& Teske, P. (1993b). The pro-growth entrepreneur in local government. Urban Affairs Review, 29(2), 316-327. 
Schneider, M., Teske, P., \& Mintrom, M. (1995). Public entrepreneurs: Agents for change in American government. Princeton University Press.

Se-Hyung, Oh. (2012). Leadership emergence in autonomous work teams. Social Behavior and Personality, $40(9), 1461-1464$.

Shamir, B., \& Howell, J. (1999). Organizational and contextual influences on the emergence and effectiveness of charismatic leadership. The Leadership Quarterly, 10(2), 257-283.

Shanahan, E., Jones, M., McBeth, M., \& Lane, R. (2013). An angel in the wind: How heroic policy narratives shape policy realities. Policy Studies Journal, 41(3), 453-483.

Sharp, E., Daley, D. M., \& Lynch, M. (2011). Understanding local adoption and implementation of climate change mitigation policy. Urban Affairs Review, 47(3), 433-457.

Silviera, S. (2000). The American environmental movement: Surviving through diversity. Boston College Environmental Affairs Law Review, 28, 497-532.

Simmons, E. (2014). Grievances do matter in mobilization. Theory and Society, 43, 513-546.

Stone, D. (2019). Transnational policy and partners in the cultivation of influence. Globalizations, 16(7), 1128-1144.

Teodoro, M. (2011). Bureaucratic ambition. Johns Hopkins.

Teske, P., \& Schneider, M. (1994). The bureaucratic entrepreneur. Public Administration Review, 54(4), $331-340$.

U.S. Census. (2000). The US Census. U.S. Census Bureau.

Vallett, J. (2020). The diffusion of Erin's Law: Examining the role of the policy entrepreneur. Policy Studies Journal (forthcoming).

Veenstra, A., Lyons, B., \& Fowler-Dawson, A. (2016). Conservatism vs. conservationism: Differential influences of social identities on beliefs about fracking. Environmental Communication, 10(3), 322-336.

Vogeler, C., \& Bandelow, N. (2018). Mutual and self-perceptions of opposing advocacy coalitions. Review of Policy Research, 35(5), 717-732.

Walsh, P. J., Bird, S., \& Heintzelman, M. (2015). Understanding local regulation of fracking. Agricultural and Resource Economics Review, 44(2), 138-163.

Weible, C., Sabatier, P., \& McQueen, K. (1999). Themes and variations: Taking stock of the Advocacy Coalition Framework. Policy Studies Journal, 37(1), 121-140.

Weissert, C. (1991). Policy entrepreneurs, policy opportunists, and legislative effectiveness. American Politics Research, 19, 262-274.

Zahariadis, N. (2007). Ambiguity and multiple streams. In P. A. Sabatier (Ed.), Theories of the policy process (2nd ed., pp. 65-92). Westview Press.

Publisher's Note Springer Nature remains neutral with regard to jurisdictional claims in published maps and institutional affiliations. 